\title{
Phytohormone Responses and Cell Viability during Salinity Stress in Two Creeping Bentgrass Cultivars Differing in Salt Tolerance
}

\author{
Sanalkumar Krishnan and Emily B. Merewitz ${ }^{1}$ \\ Department of Plant, Soil, and Microbial Sciences, Michigan State University, 1066 Bogue Street, \\ East Lansing, MI 48824
}

\begin{abstract}
AdDitional INDEX words. plant hormones, abiotic stress, osmotic stress, turfgrass, dye exclusion technique, Agrostis stolonifera

ABstract. Salinity stress is becoming more prevalent in turfgrass management with the increasing use of recycled water for irrigation. Creeping bentgrass (Agrostis stolonifera) is a cool-season turfgrass species that contains significant cultivar variation in salt stress tolerance, but the mechanism related to this cultivar variation is not well understood. Our objectives were to determine whether differential hormone content could play a role in cultivar variation of salt responses and to evaluate whether cell viability assays using dye techniques could differentiate salt stress damage levels in turfgrass species. Therefore, a growth chamber study with potted plants was conducted to evaluate salt ion concentrations, physiological responses, and hormone analysis [abscisic acid (ABA), indole-3-acetic acid (IAA), jasmonic acid (JA), salicylic acid (SA), zeatin riboside (ZR), and ethylene] at 4, 8, and $12 \mathrm{dS} \cdot \mathrm{m}^{-1}$ in relatively salt-tolerant 'Mariner' compared with salt-sensitive 'Penncross' creeping bentgrass. A hydroponics-based growth chamber study was performed for evaluation of whether dead-cell stains coupled with image analysis could be a quick method for indicating cell viability variation between cultivars. Greater salt tolerance was evident in 'Mariner' at $12 \mathrm{dS} \cdot \mathrm{m}^{-1}$, which showed significantly lower electrolyte leakage, higher leaf relative water content (RWC), osmotic potential, photochemical efficiency, and photochemical yield compared with 'Penncross'. A higher $\mathrm{K}^{+}$and lower $\mathrm{Na}^{+}$content was maintained in leaves of 'Mariner' compared with 'Penncross' while roots of 'Mariner' maintained higher $\mathrm{Ca}^{2+}$ content under stressed and nonstressed conditions. Phytohormone levels showed a decline in salt-stressed roots compared with nonstressed plants but 'Mariner' roots were able to maintain levels higher than 'Penncross'. 'Mariner' leaves showed an increased accumulation of ABA, JA, SA, and ZR while roots maintained higher IAA and SA compared with 'Penncross'. The results suggest that 'Mariner' was able to mitigate salt stress by better ion regulation and differential regulation of hormones compared with 'Penncross'. 'Mariner' leaves and roots showed significantly lower dead cells compared with 'Penncross' under salt stress. The results suggest that staining for cell viability could be a useful technique for studying turfgrass stress or other cellular responses.
\end{abstract}

Salt stress is increasingly becoming a major problem in turfgrass management, as golf courses and other turf areas are located on salt-laden lands, coastal areas, and areas where fresh water sources are limited. In areas where fresh water is limited or costly, the use of reclaimed water on golf courses and other turfgrass areas is a strategy to maintain sustainability and conserve water or is mandated. Depending on the source of recycled water and the growing environment to which it is applied, there are various potential pros and cons of using reclaimed water. Among other issues, the water often contains high levels of salts, potentially at high-enough concentrations to cause salt-stress damage to plants (Harivandi, 2013). But the pros of using reclaimed water, such as beneficial nutrients and cost efficiency, have allowed the use of reclaimed water to become a desirable turf management practice. Therefore, it is necessary to understand how turfgrass plants will cope with irrigation water containing high salt levels or prolonged salt exposure because of accumulated salts in soils, whether the salt stress is due to natural incidence or from use of reclaimed water.

Creeping bentgrass, the most desirable and predominant $\mathrm{C} 3$ species on golf course greens in the United States, is considered

Received for publication 22 Apr. 2015. Accepted for publication 2 June 2015. We thank the Michigan Turfgrass Foundation and AgBioResearch of Michigan State University for funding and support of this research.

${ }^{1}$ Corresponding author. E-mail: merewitz@msu.edu. moderately sensitive to salt-stress damage (Harivandi, 2013). Salinity tolerance in C4 turfgrasses was reported to be closely associated with restricted $\mathrm{Na}^{+}$accumulation in shoots (Marcum and Murdoch, 1994). Creeping bentgrass also exhibits considerable susceptibility to other abiotic and biotic stresses such as summer stress and dollar spot [Sclerotinia homoeocarpa (Fry and Huang, 2004)]. How the phytohormone profile of creeping bentgrass changes in response to salt irrigation is not yet fully understood or documented. Determination of hormone changes in response to salt stress will indicate potential salt tolerance attributes as well as potential susceptibility to other abiotic and biotic stresses during salt-stress incidence. Our results will also apply to other widely used grasses such as for forage or bioenergy. In addition, a better understanding of how hormones respond to salt stress may lead to the development of breeding methods to identify salt-tolerant cultivars via the use of these hormones as biomarkers or potential biochemical pathways to genetically alter for improved salt tolerance.

Hormonal changes in response to salt stress have been documented in other species such as wheat (Triticum aestivum) and rice (Oryza sativa) (Javid et al., 2011). However, how hormones and other metabolites respond to stress can be highly species dependent and depend on salt stress severity and duration. In addition, cultural practices such as mowing that could modify hormone contents of turfgrasses are highly different from that in other monocots used as agronomic crops. 
Significant variation in salt-stress tolerance has been found in creeping bentgrass germplasm (Marcum, 2001); however, the major physiological factors contributing to cultivar differences in salt tolerance have still not been fully elucidated. In addition, how phytohormone profiles change in response to salt stress in turfgrass species is not well investigated. Understanding how hormone profiles change will help to elucidate mechanisms governing salt-stress tolerance in creeping bentgrass.

Visual methods to measure plant cell viability by dye techniques have been used in other crop species, but have not yet been used within turf science. Researchers often encounter difficulties in the triphenyl tetrazolium chloride (TTC) method (Berridge et al., 2005) and find it difficult to isolate specific root classes, as is required in the methods of Ruf and Brunner (2003) from perennial grass species. This is largely because grasses have fine, fibrous, and dynamic root systems. Thus, investigation of additional techniques to evaluate cell viability in turfgrass species is desirable. One method to identify nonviable cells that is primarily used in flow cytometry or in fixed-tissue procedures is the use of SYTOX ${ }^{\circledR}$ dyes (Molecular Probes, Eugene, OR). These dyes are unable to penetrate live cell membranes. The dyes are able to penetrate dead cell membranes and then exhibit fluorescent properties when bound to the DNA within that dead cell. Recently, it was shown that these techniques are effective on living plant tissue of Arabidopsis thaliana (Truernit and Haseloff, 2008). Here, we aim to evaluate SYTOX dye staining procedures and which dye color is most effective to use on creeping bentgrass leaves and roots. We also aimed to determine whether the dye technique coupled with image color analysis is a quick, easy method for investigation of differential salt tolerance among turfgrass cultivars.

The objectives of this study were to understand how the major phytohormones ABA, IAA, ZR, JA, SA, and ethylene responded to salt stress in two creeping bentgrass cultivars contrasting in salt tolerance, Mariner (relatively salt tolerant) and Penncross (salt sensitive), maintained as low-mown turfgrass. In addition, we have evaluated physiological traits, cell viability, and quantified salt uptake and nutrient content of the two cultivars to determine relative tolerance levels.

\section{Materials and Methods}

Plant material and growth conditions. For the potted plant study, seeds were grown in plastic pots $(10.2 \times 10.2 \times 12.7 \mathrm{~cm})$ filled with pure sand in a growth chamber. Each treatment was represented by four pots and a total of 16 pots were used for this study. The treatments were 1) salt stressed and 2) control (optimal conditions) of each 'Mariner' and 'Penncross'. Saltstress treatment was stepwise to get to moderately high salt stress $\left(12 \mathrm{dS} \cdot \mathrm{m}^{-1}\right)$ over a prolonged period to prevent salt shock and to simulate field conditions of using potable water sources in long-term irrigation. A similar method was used by Friell et al. (2013). Ocean salt (Instant Ocean; Spectrum Brands, Blacksburg, VA) was applied to the Hoagland's solution to achieve a salt concentration of $2 \mathrm{dS} \cdot \mathrm{m}^{-1}$ and gradually increased by $2 \mathrm{dS} \cdot \mathrm{m}^{-1}$ every $2 \mathrm{~d}$ to the target level of $12 \mathrm{dS} \cdot \mathrm{m}^{-1}$. Roots were evaluated only at the conclusion of the study at $12 \mathrm{dS} \cdot \mathrm{m}^{-1}$ salt treatment because of the need for destructive sampling of the plants for measurements. Salt treatment started on 30 May 2013 and ended on 22 July 2013. The measurements were taken on 3 June, 7 June, and 22 July 2013. The growth chamber conditions included a light level of $260 \mu \mathrm{mol} \cdot \mathrm{m}^{-2} \cdot \mathrm{s}^{-1}$ with a 14-h photoperiod, $21.5{ }^{\circ} \mathrm{C}$ ambient temperature, and $65 \%$ relative humidity $(\mathrm{RH})$. Data for 4,8 , and $12 \mathrm{dS} \cdot \mathrm{m}^{-1}$ were collected on 4,8 and $52 \mathrm{~d}$ after initiation of salt treatment. Relatively low rates of salt treatment were used in the study to replicate longterm salt stress under field conditions, such as those that may be encountered with reclaimed water irrigation. Thus, it took a significant number of days for the plants to become visibly stressed under our experimental conditions. All plants were trimmed equally, as needed to achieve $\approx 2-3 \mathrm{~cm}$ canopy height.

The hydroponic, growth chamber study of plants was conducted for cell viability assays. Seeds of 'Mariner' and 'Penncross' were germinated in petri dishes and seedlings were transferred to two $15-\mathrm{L}$ containers $(42.5 \times 30.2 \times 17.8 \mathrm{~cm})$ containing half-strength Hoagland's solution (Hoagland and Arnon, 1950). Previous studies have shown that these creeping bentgrass cultivars are significantly different in performance under salt-stress conditions (Marcum, 2001). Each container was represented by 40 plants of each cultivar. One container was selected to receive the salt treatment while the other one was kept for control. The seedlings were allowed to grow and become established in nutrient solution for 1 month. Salt treatment started at $4 \mathrm{dS} \cdot \mathrm{m}^{-1}$ and then was raised to $20 \mathrm{dS} \cdot \mathrm{m}^{-1}$ via increments of $4 \mathrm{dS} \cdot \mathrm{m}^{-1}$ per day. The study started on 1 July 2014 and ended on 30 July 2104. The growth chamber conditions included light level of $560 \mu \mathrm{mol} \cdot \mathrm{m}^{-2} \cdot \mathrm{s}^{-1}$ with a 14-h photoperiod, $21.50{ }^{\circ} \mathrm{C}$ ambient temperature, and $65 \%$ RH. An air pump $\left(115 \mathrm{~V}, 60 \mathrm{~Hz}\right.$; Tetra $^{\circledR}$, Blacksburg, VA) and tube inserted into the nutrient solution was used to provide oxygen to the plant roots.

Physiological evaluation. Physiological parameters were evaluated at 4,8 , and $12 \mathrm{dS} \cdot \mathrm{m}^{-1}$ salt levels. Visual quality rating known as turf quality (TQ) was based on color, density, and uniformity of the grass canopy using a scale of $1-9$ [9= fully turgid, dense green canopy, 1 = completely dead plants (Beard, 2001)].

Leaf relative water content was determined by the Barrs and Weatherley (1962) method. Briefly, $\approx 10$ mature leaves were harvested from plants and weighed immediately to determine the fresh weight (FW). The leaves were placed in covered petri dishes filled with water and kept at $4{ }^{\circ} \mathrm{C}$ overnight to reach full hydration. Leaf samples were blotted dry and weighed immediately to determine the turgid weight (TW). Leaf tissues were dried in an oven at $80^{\circ} \mathrm{C}$ for $72 \mathrm{~h}$ and weighed to determine the dry weight (DW). RWC was calculated as $(\mathrm{FW}-\mathrm{DW}) /(\mathrm{TW}-$ DW) $\times 100$.

Electrolyte leakage (EL) was measured to approximate cellmembrane stability of leaves on $\approx 10$ leaves per sample taken from each plant by the method of Blum and Ebercon (1981). The leaves were washed with de-ionized water and immersed in $30 \mathrm{~mL}$ of de-ionized water and placed on a shaker for $24 \mathrm{~h}$. The conductivity of the water containing the living tissue was measured as initial conductivity $\left(C_{\mathrm{i}}\right)$. The leaf tissues were killed by boiling for $20 \mathrm{~min}$ and then placed on a shaker for $24 \mathrm{~h}$. The conductivity of the water containing the dead tissues was measured as the maximum conductance $\left(C_{\max }\right)$. The percentage EL was calculated as $C_{\mathrm{i}} / C_{\max } \times 100$.

Quantum yield of regulated nonphotochemical energy loss in photosystem II (YII) and photochemical efficiency $\left(\mathrm{F}_{\mathrm{v}} / \mathrm{F}_{\mathrm{m}}\right)$ were measured on attached leaves with two subsamples per plant using a fluorimeter instrument (OSp5; Opti-Sciences, Hudson, NH). 
Osmotic potential was determined based on the osmotic potential of fully rehydrated leaves $\left(\Psi_{\pi 100}\right)$ as in the work of Rachmilevitch et al. (2006). Turgid leaf samples were frozen in liquid nitrogen. Leaf sap was expressed from leaves manually using a micropestle and microcentrifuge tube. A vapor pressure osmometer (Vapro ${ }^{\odot}$ model 5600; Wescor, Logan, UT) was used to determine osmolality [C (millimoles per kilogram)] operating at $22{ }^{\circ} \mathrm{C}$. Osmolality of cell sap was converted to osmotic potential in $\Psi_{\mathrm{S}}$ (megapascals) using the formula: $\Psi_{\mathrm{S}}=-\mathrm{C} \times 2.58 \times 10^{-3}$ (DaCosta and Huang, 2006).

SYTOX DYE METHOD FOR QUANTIFICATION OF ROOT AND LEAF CELL VIABILITY. Salt stress damage to leaves and roots of 'Mariner' and 'Penncross' plants were visually quantified using SYTOX blue, green, and orange dyes. SYTOX dyes penetrate the plasma membrane of dead cells and exhibit bright fluorescence after preferentially binding to DNA, but are not able to penetrate living cells (Roth et al., 1997; Truernit and Haseloff, 2008). Therefore, we have conducted a hydroponics study to test the efficacy of SYTOX blue dye in differentiating the viable and dead leaf and root cells of 'Mariner' and 'Penncross' under salt stress using confocal microscopy. Leaves and roots $\approx 2.0 \mathrm{~cm}$ long were harvested from randomly selected plants from each treatment within the hydroponic growth chamber study.
A total of 40 plants were subjected to image analysis with 10 plants representing each treatment. Tissue samples were incubated in $250 \mathrm{nM}$ SYTOX blue dye for $20 \mathrm{~min}$ (Truernit and Haseloff, 2008). The tissues were rinsed with distilled water for 2 min to remove excess dye and imaged using a laser scanning confocal microscope (FV1200; Olympus, Center Valley, PA). The percent SYTOX dye fluorescence in the images obtained from confocal microscopy of the roots and leaves cells were quantified using ImageJ software (Abramoff et al., 2004). The leaf or root tissue area in an image with $10 \times$ magnification was selected manually using the freehand selection tool in ImageJ. Root images were taken $\approx 1.0 \mathrm{~cm}$ above the root cap portion and leaf images were taken $1.0 \mathrm{~cm}$ below the leaf tip to ensure sampling similarity within replication and among treatments. The entire area of a single leaf/root tissue within an image was selected for the analysis and within the selected area, the percent fluorescence area to the nonstained area was calculated. Tissue damage is positively correlated to blue dye fluorescence.

Hormone Quantification. Phytohormone extraction and quantification was based on the method used by Liu et al. (2012). About $200 \mathrm{mg}$ of leaf and tissue samples were preserved in liquid nitrogen and ground with mortar and pestle in the presence of liquid nitrogen. Extractions were handled in the
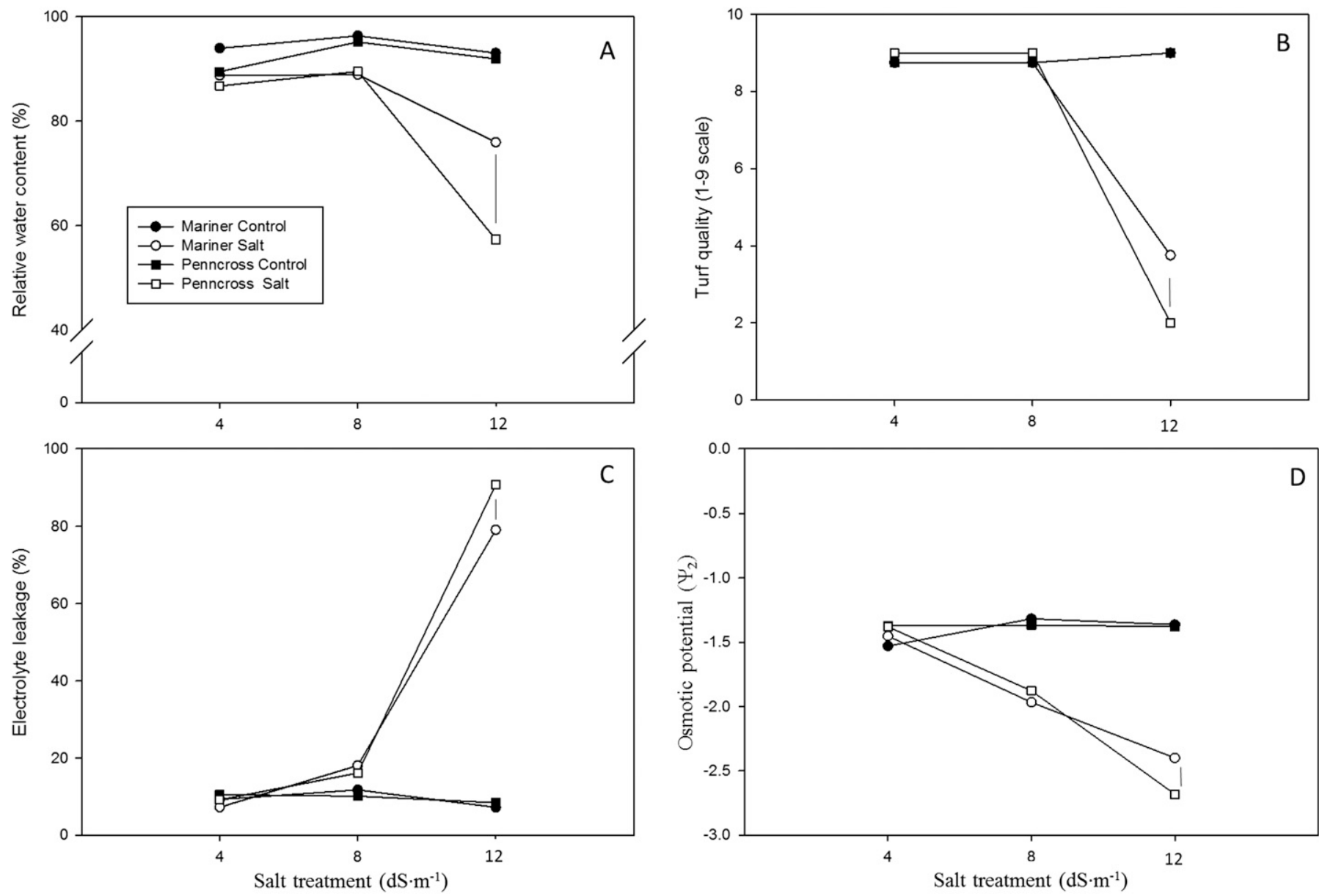

Fig. 1. (A) Relative water content, (B) turf quality, (C) electrolyte leakage, and (D) osmotic potential of 'Mariner' and 'Penncross' creeping bentgrass. The data collected on 4,8 , and $52 \mathrm{~d}$ after treatment corresponds to 4,8 , and $12 \mathrm{dS} \cdot \mathrm{m}^{-1}$ salt levels, respectively. Turf quality was based on a scale of $1-9$ ( 9 representing a fully turgid, dense green canopy and 1 representing completely dead plants). Treatment means were separated using Fisher's protected least significant difference $(\mathrm{LSD})(\mathrm{n}=4)$ and days that have LSD bars indicate significant treatment difference $(P \leq 0.05)$. LSD bars were only included for days where statistical differences were observed. 
same manner as described for kentucky bluegrass (Poa pratensis) in the work of Krishnan and Merewitz (2014). The internal standards for liquid chromatography (LC) analysis included $100 \mathrm{nmol}$ of deuterium-labeled ABA. LC was carried out using an ultra-high-performance liquid chromatographytandem mass spectrometer [UPLC/MS/MS (Quattro Premier XE ACQUITY ${ }^{\circledR}$ Tandem Quadrupole; Waters, Milford, MA)].

ETHYLENe PRODUCTION. The rate of evolution of ethylene was determined on the full canopy of plants with a portable ethylene gas analyzer (CI-900; CID Bio-Science, Camas, WA). The pots were kept inside the airtight chamber of the instrument for $2 \mathrm{~min}$ and the rate of ethylene evolution (microliters per cubic meter). Because of instrument upgrades and repair required during the study, only ethylene data are available at $12 \mathrm{dS} \cdot \mathrm{m}^{-1}$.

NutRiEnt ANALYsis. About $100 \mathrm{mg}$ of oven-dried leaf and root tissue was homogenized in $1 \mathrm{~mL}$ concentrated nitric acid. The extract was analyzed for $\mathrm{Na}^{+}, \mathrm{K}^{+}$, and $\mathrm{Ca}^{2+}$ using an inductively coupled plasma mass spectrometer [ICP-MS (ICAP Q; Thermo Fisher Scientific, Waltham, MA)].

EXPERIMENTAL DESIGN AND STATISTICAL ANALYSIS. A completely randomized design was used for the potted study with
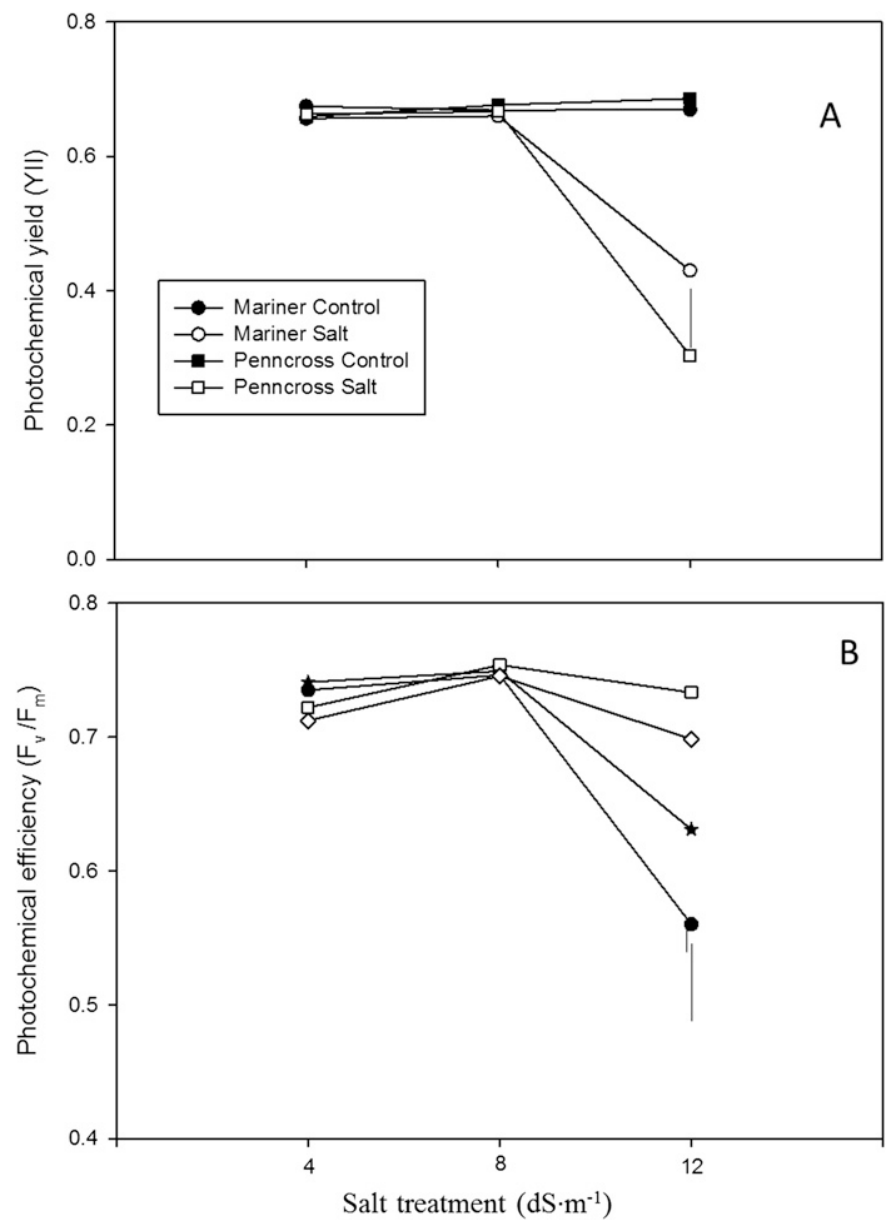

Fig. 2. Photochemical attributes including (A) photosynthetic yield (YII) and (B) photochemical efficiency $\left(\mathrm{F}_{\mathrm{v}} / \mathrm{F}_{\mathrm{m}}\right)$ of 'Mariner' and 'Penncross' creeping bentgrass. The data collected on 4,8 , and $52 \mathrm{~d}$ after treatment corresponds to 4,8 , and $12 \mathrm{dS} \cdot \mathrm{m}^{-1}$ salt levels, respectively. Treatment means were separated using Fisher's protected least significant difference $(\mathrm{LSD})(\mathrm{n}=4)$ and days that have LSD bars indicate significant treatment difference $(P \leq 0.05)$. four individual plants serving as the replications per treatment. A completely randomized block design was used for the hydroponic study with 40 individual plants for each cultivar randomized within the containers. Analysis of variance was based on the general linear model procedure of SAS (version 9.1; SAS Institute, Cary, NC). The Fisher's protected least significant difference (LSD) test at the $0.05 P$ level was used to detect the difference between treatment means. LSD bars were presented in the figures where a significant effect was observed.
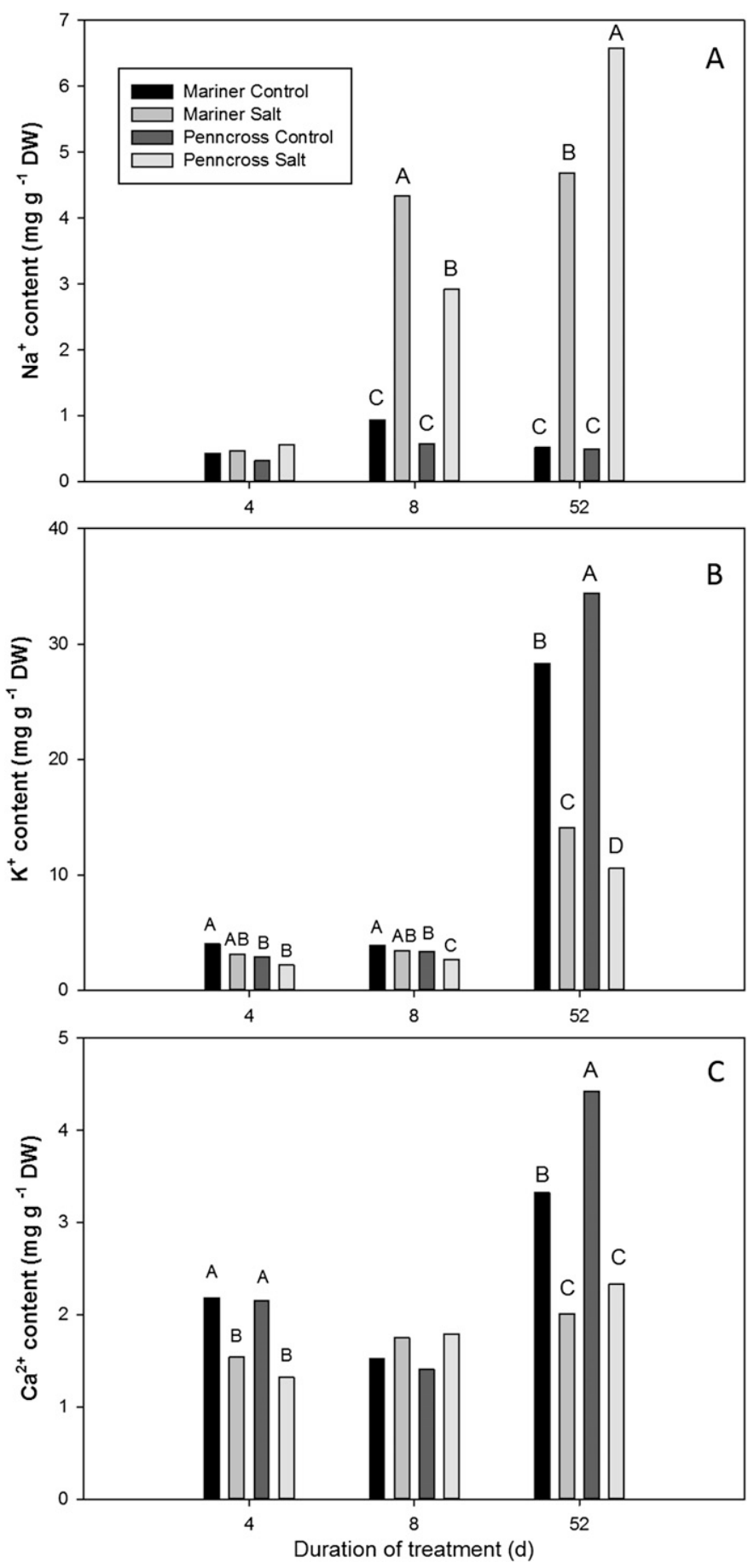

Fig. 3. Leaf content of (A) $\mathrm{Na}^{+},(\mathbf{B}) \mathrm{K}^{+}$, and (C) $\mathrm{Ca}^{2+}$ in 'Mariner' and 'Penncross' creeping bentgrass at 4,8 , and $12 \mathrm{dS} \cdot \mathrm{m}^{-1}$ salt level. Bars with different letters indicate significant treatment differences $(P \leq 0.05)$. NS $=$ nonsignificant. 


\section{Results}

RWC of salt-stressed plants was significantly lower at 8 and $12 \mathrm{dS} \cdot \mathrm{m}^{-1}$ compared with controls (Fig. 1A). 'Mariner' showed significantly higher RWC at $12 \mathrm{dS} \cdot \mathrm{m}^{-1}$ compared with 'Penncross' under salt stress. TQ of salt-stressed 'Mariner' and 'Penncross' did not differ significantly at 4 and $8 \mathrm{dS} \cdot \mathrm{m}^{-1}$, but were significantly lower at $12 \mathrm{dS} \cdot \mathrm{m}^{-1}$ compared with nonsalttreated plants (Fig. 1B). Better TQ was maintained by 'Mariner' compared with 'Penncross' at $12 \mathrm{dS} \cdot \mathrm{m}^{-1}$. EL of salt-stressed 'Mariner' and 'Penncross' at 4 and $8 \mathrm{dS} \cdot \mathrm{m}^{-1}$ were not different from controls, but a $12 \%$ decrease in EL was observed in 'Mariner' compared with 'Penncross' at $12 \mathrm{dS} \cdot \mathrm{m}^{-1}$ (Fig. 1C). Photosynthetic characteristics such as $\mathrm{F}_{\mathrm{v}} / \mathrm{F}_{\mathrm{m}}$ and YII for control plants were consistent at $\approx 0.67$ during the treatment days. Salt stress reduced $\mathrm{F}_{\mathrm{v}} / \mathrm{F}_{\mathrm{m}}$ and YII of both cultivars at $12 \mathrm{dS} \cdot \mathrm{m}^{-1}$ compared with control but 'Mariner' showed $12.5 \%$ and $41.7 \%$ higher $\mathrm{F}_{\mathrm{v}} / \mathrm{F}_{\mathrm{m}}$ and $\mathrm{YII}$, respectively, compared with 'Penncross' (Fig. 2A and B). Osmotic potential was significantly lower in salt-stressed plants compared with controls. At $12 \mathrm{dS} \cdot \mathrm{m}^{-1}$, 'Mariner' exhibited significantly higher osmotic potential compared with 'Penncross' (Fig. 1D).

$\mathrm{Na}^{+}$accumulated in leaves in both cultivars because of growth in the salt solution, but 'Mariner' had a significantly lower $\mathrm{Na}^{+}$accumulation in leaves compared with 'Penncross' (Fig. 3A). At $12 \mathrm{dS} \cdot \mathrm{m}^{-1}$, salt-treated 'Mariner' plants had a 9-fold increase in $\mathrm{Na}^{+}$accumulation whereas 'Penncross' leaves had about a 14-fold increase. $\mathrm{Na}^{+}$accumulation in roots was high because of salt-stress treatment since both 'Mariner' and 'Penncross' plants exhibited an average of a 15 -fold increase in root $\mathrm{Na}^{+}$content (Fig. 5A). There were no significant differences in root accumulation of $\mathrm{Na}^{+}$between cultivars. At $12 \mathrm{dS} \cdot \mathrm{m}^{-1}, \mathrm{Ca}^{2+}$ and $\mathrm{K}^{+}$in leaves were reduced by salt stress in both cultivars of creeping bentgrass but $\mathrm{K}^{+}$was reduced to a greater extent in
'Penncross' leaves compared with 'Mariner' leaves (Fig. 3B and C). $\mathrm{K}^{+}$was least affected by cultivar and salt treatment. A significantly greater $\mathrm{K}^{+}$was detected in 'Mariner' control roots compared with other treatments but the level of change may not be practically significant (Fig. 5A). The root $\mathrm{Ca}^{2+}$ content of control and salt-stressed 'Mariner' plants were both significantly higher than the control and salt-stressed 'Penncross' plants. There was no statistically significant change in $\mathrm{Ca}^{2+}$ of roots in response to salt stress within a given cultivar (Fig. 5A).

Hormone CONTENT. ABA content of creeping bentgrass leaves increased in both cultivars in response to salt treatment (Fig. 4A). At $8 \mathrm{dS} \cdot \mathrm{m}^{-1}$ salt treatment, ABA content of leaves rose to levels significantly greater than that in control plants. At $12 \mathrm{dS} \cdot \mathrm{m}^{-1}$ exposure, 'Mariner' plants had a greater accumulation of ABA compared with 'Penncross'. ABA content of roots was the same for both cultivars under control conditions, and salt stress caused a reduction in $\mathrm{ABA}$ accumulation in roots in both cultivars at $12 \mathrm{dS} \cdot \mathrm{m}^{-1}$ (Fig. 5B).

IAA and ZR content of leaves was highly increased because of salt stress in both cultivars (Fig. 4B and C). At $12 \mathrm{dS} \cdot \mathrm{m}^{-1}$, the content of IAA in salt-stressed 'Penncross' plants was significantly higher than in 'Mariner' plants; however, relative to the IAA content of their respective controls, about a 100-fold increase was observed for both cultivars. A different trend was observed regarding IAA content of roots because salt stress did not change IAA content in 'Mariner' but caused a $66 \%$ reduction in root IAA content of 'Penncross' plants (Fig. 5B). In regard to ZR levels between cultivars, there was a bigger increase in leaf content of ZR in 'Mariner' in response to salt stress compared with the increase observed in 'Penncross' leaves. No significant differences were detected in root ZR content due to cultivar difference or salt treatment (Fig. 5B).
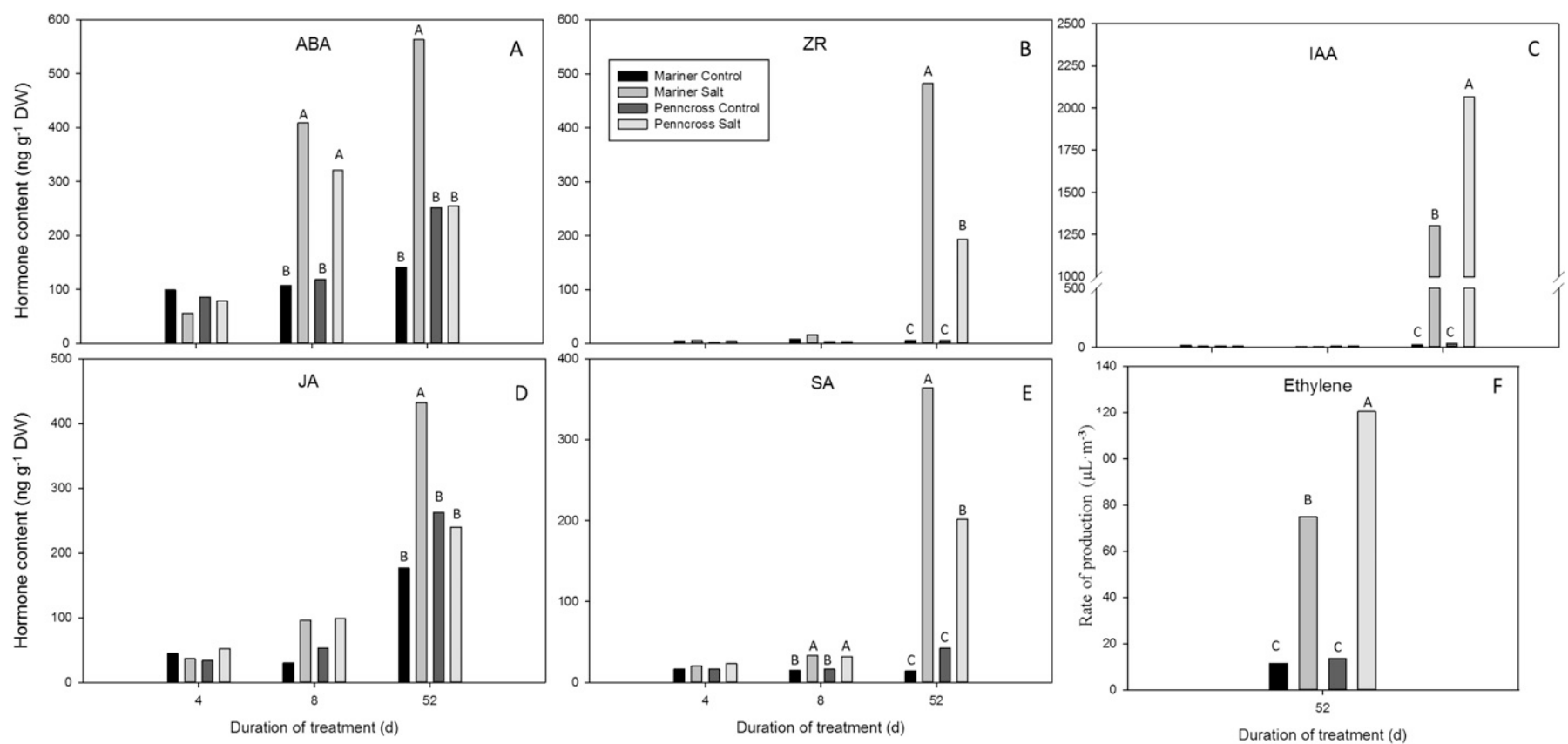

Fig. 4. Leaf content of (A) abscisic acid (ABA), (B) zeatin riboside (ZR), (C) indole-3-acetic acid (IAA), (D) jasmonic acid (JA), (E) salicylic acid (SA), and evolution of $(\mathbf{F})$ ethylene in 'Mariner' and 'Penncross' creeping bentgrass leaves at 4,8 , and $12 \mathrm{dS} \cdot \mathrm{m}^{-1}$ of salt treatment. Treatment means were separated using Fisher's protected least significant difference $(\mathrm{LSD})(\mathrm{n}=4)$. Bars with different letters indicate significant treatment differences $(P \leq 0.05)$. 

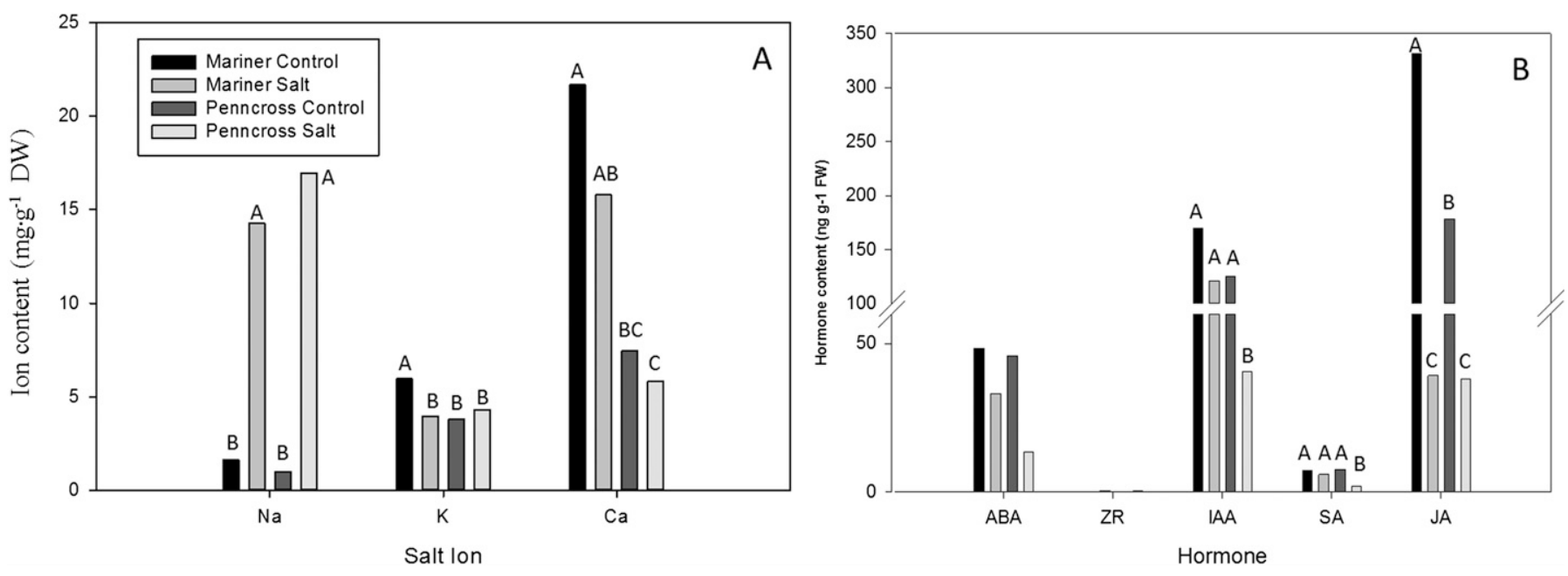

Fig. 5. (A) Ion content and (B) hormone contents of 'Mariner' and 'Penncross' creeping bentgrass roots at $12 \mathrm{dS} \cdot \mathrm{m}^{-1}$ of salt treatment. Treatment means were separated using Fishers protected LSD $(n=4)$. Bars with different letters indicate significant treatment differences $(P \leq 0.05)$.

Salt stress caused an increase in JA content of leaves in 'Mariner' but not in 'Penncross' at $12 \mathrm{dS} \cdot \mathrm{m}^{-1}$. Salt-stressed 'Mariner' plants had a $144 \%$ increase in JA content relative to the control plants at $12 \mathrm{dS} \cdot \mathrm{m}^{-1}$ (Fig. 4D). In contrast, JA content of roots decreased because of salt stress in both cultivars. Approximately a 4.7-fold decrease in JA occurred in 'Penncross' and an 8.4-fold decrease in 'Mariner' (Fig. 5B).

The leaves of 'Mariner' creeping bentgrass had a greater content of SA compared with 'Penncross' plants at $12 \mathrm{dS} \cdot \mathrm{m}^{-1}$ of salt treatment (Fig. 4E). Salt stress caused an increase in SA content in the leaves of both creeping bentgrass cultivars; however, the increase was significantly greater in 'Mariner' than in 'Penncross'. No significant change in SA content of roots was detected in response to salt stress in either cultivar (Fig. 5). The rate of ethylene evolution was significantly higher in salt-stressed cultivars compared with controls. 'Penncross' showed $60 \%$ higher ethylene production than 'Mariner' at 12 $\mathrm{dS} \cdot \mathrm{m}^{-1}$ (Fig. 4F).

LeAF AND Root VIABILITY. The SYTOX blue dye was the most effective and visible stain for creeping bentgrass leaves and roots in our study. In initial tests, the orange and green dyes were not as effective when compared with blue in our tests on creeping bentgrass tissues (data not shown). Reasons for this are unknown and could not be determined from the scope of our tests. Thus, for the hydroponic study presented here, we only used SYTOX blue dye. The fluorescence images from the confocal scanning images showed that SYTOX dye bound to cells in both leaves and roots of 'Mariner' and 'Penncross' (Figs. 7 and 8). Since this dye is only able to penetrate nonviable cells, we can assume that the staining was present in cells adversely affected by salt-stress damage. Little to no stain was observed in control leaves or roots of both cultivars. The SYTOX staining of the control leaves and roots was less than $2 \%$ of the total tissue area imaged while the salt-treated plants showed greater than $50 \%$ and $25 \%$ damage in leaves and roots, respectively. Significantly higher nonviable cells were observed in 'Penncross' leaves and roots compared with 'Mariner' leaves and roots. 'Mariner' had 25\% fewer dead leaf cells and $23 \%$ less death of root cells compared with 'Penncross' (Fig. 6).

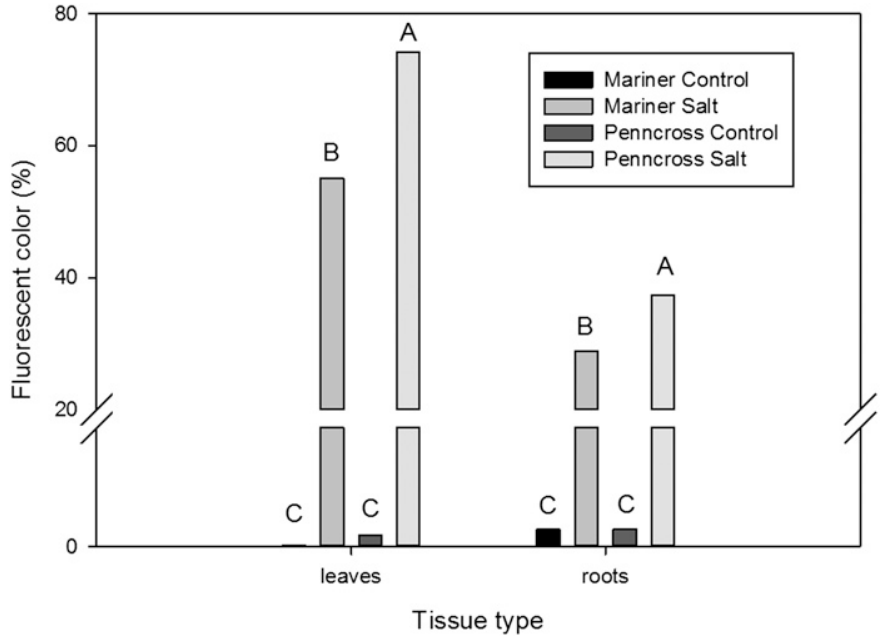

Fig. 6. Leaf and root cell viability of salt-stressed 'Mariner' and 'Penncross' creeping bentgrass. SYTOX $®$ blue (Molecular Probes, Eugene, OR) fluorescence in leaf and root cells were quantified using ImageJ software (Abramoff et al., 2004). Treatment means were separated using Fisher's protected LSD $(\mathrm{n}=10)$. Bars with different letters indicate significant treatment differences within a given tissue type $(P \leq 0.05)$.

\section{Discussion}

Increasing prevalence of the use of reclaimed water and use of turfgrasses in salt-prone environments has caused a great need for investigation of salt-stress tolerance mechanisms of turfgrass species. Salt stress is a combined stress since it can cause osmotic stress to plants as well as direct toxicity to plants due to $\mathrm{Na}^{+}$toxicity (Parida and Das, 2005).

We have evaluated salt ion concentrations, physiological responses, and hormone analysis to understand how this complex stress may affect creeping bentgrass plants and how 'Mariner' creeping bentgrass may survive salt stress better than 'Penncross' creeping bentgrass. 'Mariner' plants exhibited greater salt-tolerance attributes compared with 'Penncross' at $12 \mathrm{dS} \cdot \mathrm{m}^{-1}$ salt treatment including less $\mathrm{EL}$, greater $\mathrm{RWC}$, greater $\mathrm{TQ}$, higher $\mathrm{F}_{\mathrm{v}} / \mathrm{F}_{\mathrm{m}}$, and higher YII. At $12 \mathrm{dS} \cdot \mathrm{m}^{-1}$ 
1

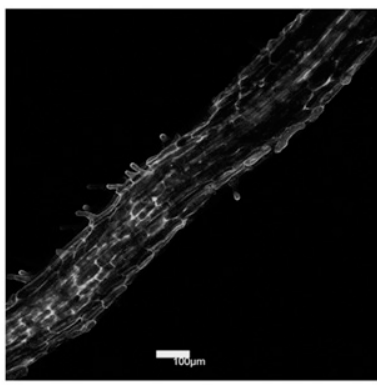

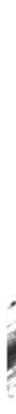

2
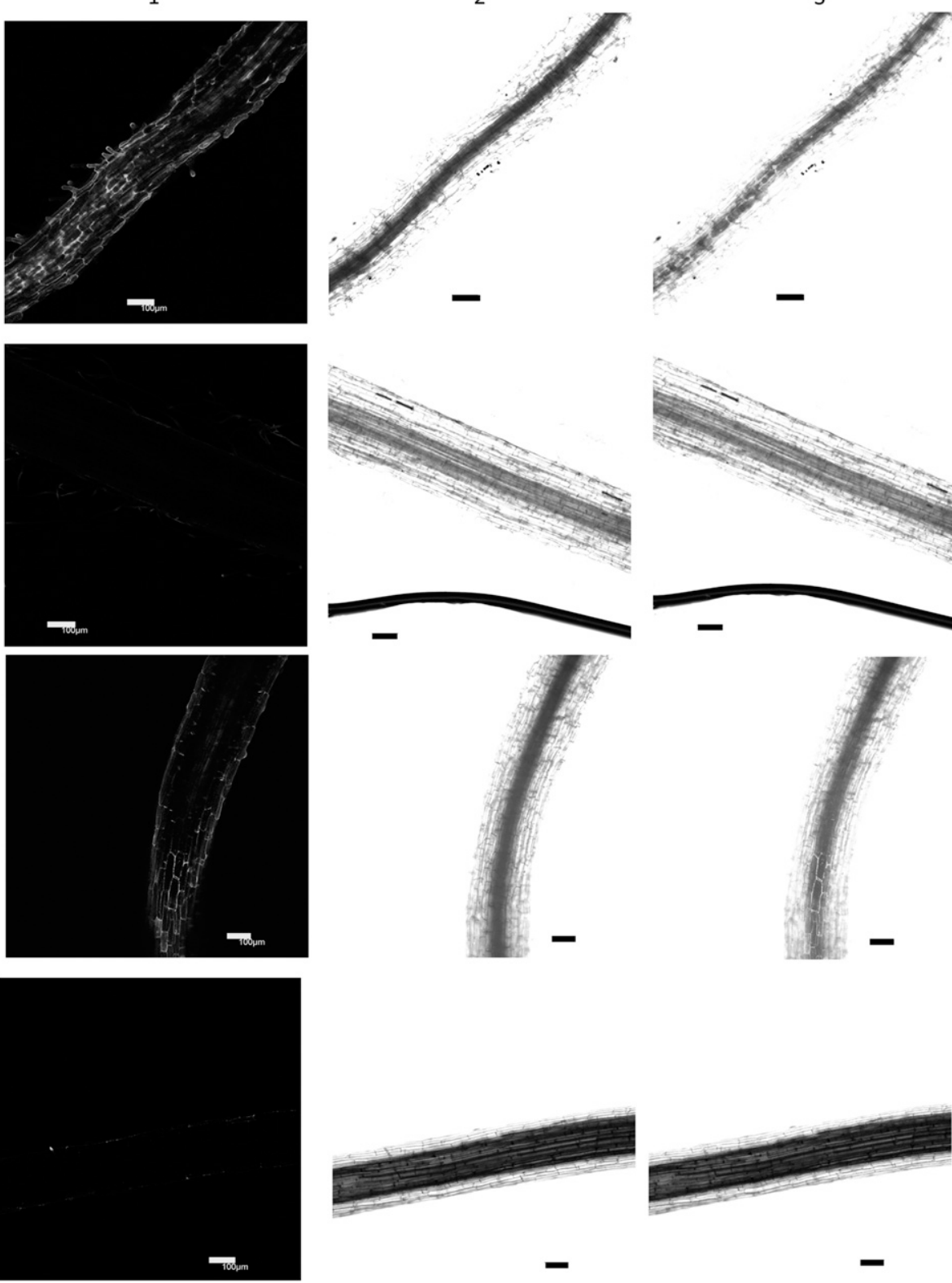

Fig. 7. SYTOX blue dye staining in roots of salt-stressed and control 'Mariner' and 'Penncross' creeping bentgrass for (A) 'Penncross' salt-stressed root, (B) 'Penncross' control root, (C) 'Mariner' salt-stressed root, and (D) 'Mariner' control root. The column 1 shows the confocal optical section of SYTOX blue channel, column 2 shows the bright field channel, and column 3 shows the merged SYTOX blue and bright field channels. White or black bar $=100 \mu \mathrm{m}$. The degree of tissue damage is positively correlated to the blue dye fluorescence in these images, which is visualized as the intensity of the white color in the images.

'Mariner' plants showed better osmotic potential than 'Penncross' suggesting its ability to maintain better turgor pressure and growth under salinity stress.

Salt ion analysis has revealed significantly different accumulation of $\mathrm{Na}^{+}, \mathrm{K}^{+}$, and $\mathrm{Ca}^{2+}$ between the two cultivars in response to salt stress. Under prolonged moderate salt-stress conditions, the $\mathrm{Na}^{+}$content of leaves of 'Mariner' was significantly lower than in 'Penncross', whereas the content of $\mathrm{Na}^{+}$in roots was slightly lower in 'Mariner' but was not significantly different between the two cultivars. Generally, plants that have the ability to excrete, exclude, or tolerate high levels of salt are more salt-stress resistant (Krishnan and
Brown, 2009). Differential expression of $\mathrm{Na}^{+}$uptake and transporters could play a role in causing differential accumulation of $\mathrm{Na}^{+}$in plant leaves and roots between cultivars. In a proteomics study, $\mathrm{H}^{+}$-ATPase content in roots were found to be greater in the more salt-tolerant 'PennA4' creeping bentgrass compared with 'Penncross'. The authors conclude that root salt tolerance may be caused by these transporters increasing $\mathrm{Na}^{+}$sequestration into central vacuoles (Xu et al., 2010). This would suggest that root $\mathrm{Na}^{+}$ content may be differential between the cultivars they investigated. $\mathrm{Na}^{+}$ analysis of tissues was not performed in their study. We did not find significant differences in salt accumulation of roots of two cultivars contrasting in salt tolerance but there were significant differences in leaf accumulation of $\mathrm{Na}^{+}$. Differential accumulation of $\mathrm{Na}^{+}$in leaves and roots was also shown to be a factor in different cultivars of grape [Vitis vinifera (Stevens et al., 1996)]. Reduced transport of $\mathrm{Na}^{+}$ from roots to shoots also may play a role in plant tolerance of salt stress (Estan et al., 2005). A better understanding of $\mathrm{Na}^{+}$movement and accumulation in creeping bentgrass is still needed.

Higher $\mathrm{Ca}^{2+}$ content was determined in 'Mariner' roots compared with 'Penncross' under both nonstressed and salt-stressed conditions. Plants accumulate $\mathrm{Ca}^{2+}$ in response to salt stress for stress perception and signaling as well as stabilization of membranes and cell walls (Hadi and Karimi, 2012; Hirschi, 2004). Perhaps a higher level of $\mathrm{Ca}^{2+}$ under nonstressed conditions allows for enhanced stress perception, signaling, or $\mathrm{Ca}^{2+}$ induced stabilization of cell structure at the onset of salt stress. Exogenous application of calcium before stress onset or calcium supplementation during stress has been shown to improve salinity tolerance in various plant species (El-Hamdaoui et al., 2003). A reduction in $\mathrm{K}^{+}$was observed in both cultivars of creeping bentgrass due to salt stress but a higher $\mathrm{K}^{+}$was maintained in leaves of 'Mariner' plants compared with 'Penncross'. This could be associated with the increase in $\mathrm{Ca}^{2+}$ since $\mathrm{Ca}^{2+}$ is known to improve membrane integrity, which prevents $\mathrm{K}^{+}$ leakage from cells. Calcium can also improve $\mathrm{K}^{+}$transport under salt-stress conditions (Cachorro et al., 1993; Maathuis, 2006). Whether the maintenance of $\mathrm{Ca}^{2+}$ in roots and $\mathrm{K}^{+}$in leaves in 'Mariner' creeping bentgrass plants under salt stress is 

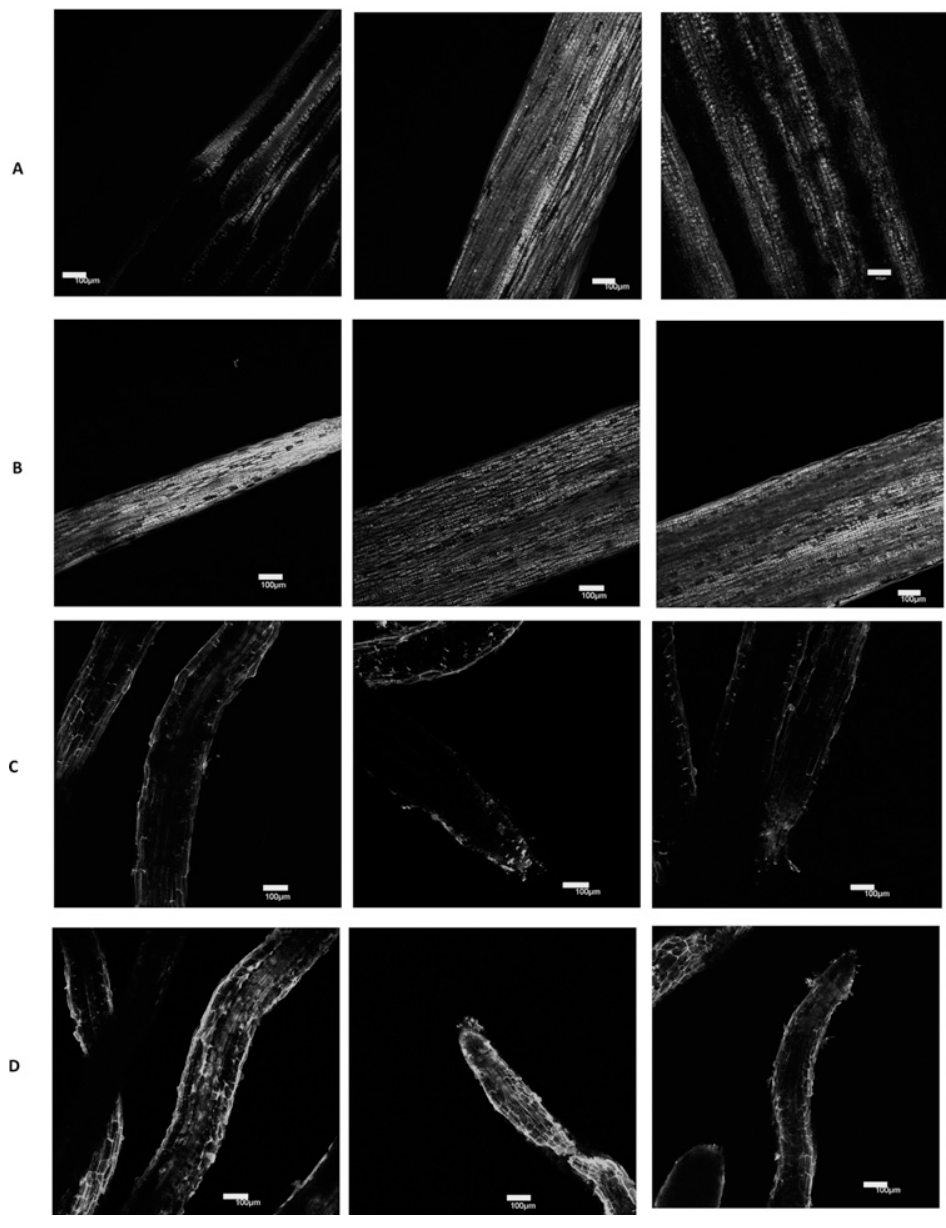

Fig. 8. Confocal optical section of SYTOX blue channel staining in leaves of (A1-3) salt-stressed 'Mariner', (A4) control 'Mariner', (B1-3) salt-stressed 'Penncross', and (B4) control 'Penncross' creeping bentgrass. Root images of salt-stressed (C1-3) and control (C4) 'Mariner' and salt-stressed (D1-3) and control (D4) 'Penncross' creeping bentgrass; Scale bar $=100 \mu \mathrm{m}$. The degree of tissue damage is positively correlated to the blue dye fluorescence in these images, which is visualized as the intensity of the white color in the images.
4
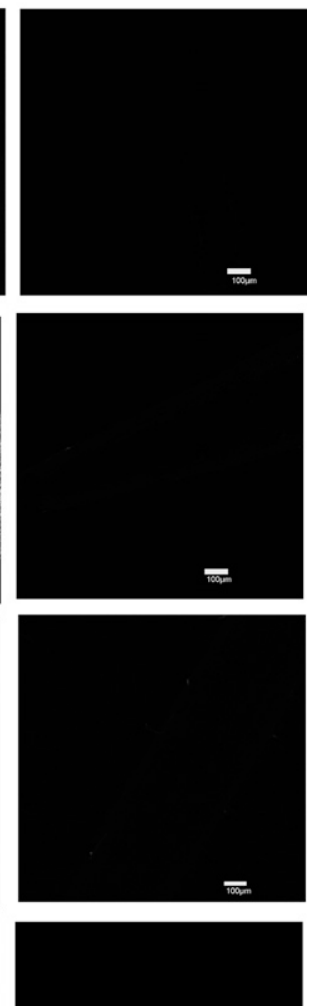

induced systemic resistance pathways. SA and JA have also been associated with critical responses to abiotic stresses including salt stress (Clouse and Sasse, 1998). They act antagonistically to each other, often described by analogy to a light switch within plants (Gupta and Huang, 2014). However, recent research has revealed that the interactions of these hormones with each other and with other hormones are increasingly more complex than previously thought in various crop species. In this study, we have observed that SA was reduced in 'Penncross' but not in 'Mariner' because of salt stress in both leaves and roots. Shakirova et al. (2003) reported that endogenous SA increased salt stress tolerance in wheat seedlings. Pretreatment in $A$. thaliana with SA resulted in improved $\mathrm{K}^{+}$retention in roots under salt stress thereby suggesting that SA could ameliorate salt-stress symptoms. SA induction could ameliorate abiotic stress such as water deficit on cell membrane by upregulating ABA and proline (Bandurska and Stroinski, 2005). We observed elevated JA in leaves of 'Mariner' compared with 'Penncross' under salt stress. JA elevation can induce pathogen defense, reduce leaf abscission, and regulate salinity and osmotic stress (Javid et al., 2011). Several studies suggest that exogenous JA application alle-

related to $\mathrm{Na}^{+} / \mathrm{H}^{+}$antiporters or other transport pumps is not yet known.

Maintenance of IAA content of roots could be a factor governing the difference in salt tolerance among these two creeping bentgrass cultivars. Evidence suggests that root IAA content plays a major role in determining the salt-stress tolerance of plants. Barrel medic (Medicago trunculata) plants are legumes that were observed to be more salt-tolerant when inoculated with an IAA-overproducing nodular bacteria compared with a wild type bacterial strain (Bianco and Defez, 2009). In bean [Phaseolus sp. (Yurekli et al., 2004)] and tomato [Lycopersicon pennellii (Yurekli et al., 2001)], salt-tolerant plants had enhanced or maintained control levels of IAA compared with more saltsensitive types in each study. In response to salinity, the saltresistant maize (Zea mays) identified by Zorb et al. (2013) maintained IAA concentration in roots. In this study, saltstressed 'Mariner' roots maintained higher IAA content than 'Penncross' and the levels in 'Mariner' were similar to control plants suggesting that IAA could aid in root survival in saline conditions or be a result of less stress damage.

SA and JA are largely known to be involved in the responses to biotic pathogens in the systemic acquired resistance and

viated salt-stress response by enhancing antioxidant activity in wheat and soybean (Glycine max) by increasing activity of superoxide dismutase, peroxidase, and catalase (Qiu et al., 2014). How JA and SA relate to stress tolerance in turfgrass species deserves further investigation; it is particularly needed for a better understanding of how the prolonged use of irrigation water containing high salts will affect tolerance levels to biotic stresses.

ABA acts as root-to-shoot signal and is upregulated by both salinity and drought stress. Root exposure of barley (Hordeum vulgare) to $\mathrm{NaCl}$ lead to $\mathrm{ABA}$ upregulation in roots and enhanced ion accumulation in vacuoles leading to better salt adaptation (Jeschke et al., 1997). In this study, 'Mariner' showed lower $\mathrm{Na}^{+}$levels, higher $\mathrm{K}^{+}$, and elevated ABA content in leaves suggesting a possible role of ABA in regulating ion homeostasis under salinity. ABA regulates $\mathrm{K}^{+}$ fluxes, $\mathrm{K}^{+}$channels, and membrane potential in roots cells; it also is well known to regulate ion transport in guard cells, which regulate stomatal aperture (Roberts and Snowman, 2000). Zorb et al. (2013) found that salt-tolerant maize showed elevated ABA content under salinity stress and suggested that ABA could contribute to apoplast acidification and enhanced growth. In turfgrass species, ABA also 
has been shown to play a role in protection from salinity damages. Creeping bentgrass and kentucky bluegrass had less membrane damage and greater antioxidant responses due to exogenous application of ABA to plants under salt stress (Yang et al., 2012). Whether ABA plays a specific regulatory role in the interaction with other phytohormone responses in salt responses of turfgrass species is not yet known.

Cytokinins (CKs) regulate several plant growth development processes including cell division, apical dominance, leaf senescence, vascular differentiation, and shoot differentiation (Davies, 2004). ZR and its derivatives are the most important group of isoprenoid CK. CK are often considered as ABA antagonists and auxin antagonists/synergists in various processes in plants (Pospisilova, 2003). Studies suggest that CK could increase salt tolerance in wheat plants by interacting with other plant hormones, especially, auxins and ABA (Iqbal et al., 2006). We found higher upregulation of $Z R$ in leaves of saltstressed 'Mariner' than 'Penncross' suggesting its involvement in delaying senescence processes and aiding in cell division and growth under salt stress. Evidence of delayed senescence was also observed in this study by the lower rate of ethylene production in 'Mariner' plants under stress. However, more isoforms of $\mathrm{CK}$ and their regulation related to salt tolerance of creeping bentgrass still need to be evaluated before making major conclusions related to $\mathrm{CK}$ and salt incidence in creeping bentgrass.

In this study, we have also evaluated a SYTOX dye staining technique to quantify nonviable leaf and root cells under salt stress using 'Mariner' and 'Penncross' creeping bentgrass. Significantly higher dye was detected in salt-treated plants compared with control plants and a greater number of nonviable cells were observed in 'Penncross' compared with 'Mariner' under salt stress. This suggests that SYTOX dye could be effectively used for evaluating turfgrass responses to environmental stresses and for other research purposes. Previously, the only technique widely used in turfgrass species to indicate cell viability has been the TTC method of root viability (Knievel, 1973), which often has not provided results that distinguish cultivars in stress tolerance levels within perennial turfgrass species with dynamic, fibrous root systems (as in McCann and Huang, 2008).

In conclusion, 'Mariner' was able to exclude effectively $\mathrm{Na}^{+}$ in leaves and maintain better $\mathrm{K}^{+}$in leaves and roots while maintaining higher $\mathrm{Ca}^{2+}$ in roots compared with 'Penncross' under salt stress. Phytohormones act as a primary signal leading to a cascade of events responsible for the plant adaptation to stress. Salt stress lead to elevated levels of ABA, IAA, JA, SA, and ZR in leaves of 'Mariner' and 'Penncross' under salt stress compared with control. Salttolerant 'Mariner' plants showed significantly higher levels of ABA, JA, SA, and ZR and lower levels of IAA in leaves compared with sensitive 'Penncross' under salt stress. The root hormone levels in salt-stressed cultivars were lower compared with nonstressed plants but 'Mariner' plants were able to maintain higher content than 'Penncross'. These results suggest that differential phytohormone regulation such as elevated $\mathrm{ABA}, \mathrm{JA}, \mathrm{SA}$, and ZR may be associated with salt tolerance in creeping bentgrass. The ability of creeping bentgrass to accumulate protective salts such as $\mathrm{Ca}^{2+}$ but not accumulate harmful salt ions such as $\mathrm{Na}^{+}$may also play a role in salt-stress survival of creeping bentgrass.

\section{Literature Cited}

Abramoff, M.D., P.J. Magalhaes, and S.J. Ram. 2004. Image processing with ImageJ. Biophotonics Intl. 11:36-42.

Bandurska, H. and A. Stroinski. 2005. The effect of salicylic acid on barley response to water deficit. Acta Physiol. Plant. 27:379-386.

Barrs, H.D. and P.E. Weatherley. 1962. A re-examination of the relative turgidity techniques for estimating water deficits in leaves. Austral. J. Biol. Sci. 15:413-428.

Beard, J.B. 2001. Turf management for golf courses. 2nd ed. Ann Arbor Press, Chelsea, MI.

Berridge, M.V., M.H. Patries, and A.S. Tan. 2005. Tetrazolium dyes as tools in cell biology: New insights into their cellular reduction. Biotechnol. Annu. Rev. 11:127-152.

Bianco, C. and R. Defez. 2009. Medicago truncatula improves salt tolerance when nodulated by an indole-3-acetic acid-overproducing Sinorhizobium meliloti strain. J. Expt. Bot. 60:3097-3107.

Blum, A. and A. Ebercon. 1981. Cell membrane stability as a measure of drought and heat tolerance in wheat. Crop Sci. 21:43-47.

Cachorro, P., A. Ortiz, and A. Cerda. 1993. Effects of saline stress and calcium on lipid composition in bean roots. Phytochemistry 32:1131-1136.

Clouse, S.D. and J.M. Sasse. 1998. Brassinosteroids: Essential regulators of plant growth and development. Annu. Rev. Plant Biol. 49:427-451.

DaCosta, M. and B. Huang. 2006. Osmotic adjustment associated with variation in bentgrass tolerance to drought stress. J. Amer. Soc. Hort. Sci. 131:338-344.

Davies, P.J. 2004. Plant hormones: Biosynthesis, signal transduction, action. Kluwer Academic Press, Dordrecht, The Netherlands.

El-Hamdaoui, A., M. Redondo-Nieto, B. Torralba, R. Rivilla, I. Bonilla, and L. Bolanos. 2003. Influence of boron and calcium on the tolerance to salinity of nitrogen-fixing pea plants. Plant Soil 251:93-103.

Estan, M.T., M.M. Martinez-Rodriguez, F. Perez-Alfocea, T.J. Flowers, and M.C. Bolarin. 2005. Grafting raises the salt tolerance of tomato through limiting the transport of sodium and chloride to the shoot. J. Expt. Bot. 56:703-712.

Friell, J., E. Watkins, and B. Horgan. 2013. Salt tolerance of 74 turfgrass cultivars in nutrient solution culture. Crop Sci. 53:1743-1749.

Fry, J. and B. Huang. 2004. Applied turfgrass science and physiology. Wiley, Hoboken, NJ.

Gupta, B. and B. Huang. 2014. Mechanism of salinity tolerance in plants: Physiological, biochemical, and molecular characterization. Intl. J. Genomics 2014:701596.

Hadi, M.R. and N. Karimi. 2012. The role of calcium in plants' salt tolerance. J. Plant Nutr. 35:2037-2054.

Harivandi, M.A. 2013. A contemporary view of recycled water irrigation. Global Sustainability 1:58-70.

Hirschi, K.D. 2004. The calcium conundrum. Both versatile nutrient and specific signal. Plant Physiol. 136:2438-2442.

Hoagland, D.R. and D.I. Arnon. 1950. The water culture method for growing plants without soil. California Agr. Expt. Sta. Res. Bul. 347. Iqbal, M., M. Ashraf, and A. Jamil. 2006. Seed enhancement with cytokinins: Changes in growth and grain yield in salt-stressed wheat plants. Plant Growth Regulat. 50:29-39.

Javid, M.G., A. Sorooshzadeh, F. Moradi, S.A.M.M. Sanavy, and I. Allahdadi. 2011. The role of phytohormones in alleviating salt stress in crop plants. Austral. J. Crop Sci. 5:726-734.

Jeschke, W.D., A.D. Peuke, J.S. Pate, and W. Hartung. 1997. Transport, synthesis and catabolism of abscisic acid (ABA) in intact plants of castor bean (Ricinus communis L.) under phosphate deficiency and moderate salinity. J. Expt. Bot. 48:1737-1747.

Knievel, D.P. 1973. Procedure for estimating ratio of living to dead root dry matter in root core sample. Crop Sci. 13:124-126.

Krishnan, S. and E.B. Merewitz. 2014. Drought stress and trinexapacethyl modify phytohormone content within kentucky bluegrass leaves. J. Plant Growth Regulat. 34:1-12. 
Krishnan, S. and R.N. Brown. 2009. $\mathrm{Na}^{+}$and $\mathrm{K}^{+}$accumulation in perennial ryegrass and red fescue accessions differing in salt tolerance. Intl. Turfgrass Soc. Res. J. 11:817-827.

Liu, H., X. Li, J. Xiao, and S. Wang. 2012. A convenient method for simultaneous quantification of multiple phytohormones and metabolites: Application in study of rice-bacterium interaction. Plant Methods 8:2.

Maathuis, F.J.M. 2006. The role of monovalent cation transporters in plant responses to salinity. J. Expt. Bot. 57:1137-1147.

Marcum, K.B. and C.L. Murdoch. 1994. Salinity tolerance mechanism of six C4 turfgrasses. J. Amer. Soc. Hort. Sci. 119:779-784.

Marcum, K. 2001. Salinity tolerance of 35 bentgrass cultivars. HortScience 36:374-376.

McCann, S. and B. Huang. 2008. Evaluation of drought tolerance and avoidance traits for six creeping bentgrass cultivars. HortScience 43:519-524.

Parida, A.K. and A.B. Das. 2005. Salt tolerance and salinity effects on plants: A review. Ecotoxicol. Environ. Saf. 60:324-349.

Pospisilova, J. 2003. Interaction of cytokinins and abscisic acid during regulation of stomatal opening in bean leaves. Photosynthetica 41:49-56.

Qiu, Z.B., J.L. Guo, A.J. Zhu, L. Zhang, and M.M. Zhang. 2014. Exogenous jasmonic acid can enhance tolerance of wheat seedlings to salt stress. Ecotoxicol. Environ. Saf. 104:202-208.

Rachmilevitch, S., M. DaCosta, and B. Huang. 2006. Physiological and biochemical indicators for stress tolerance, p. 321-356. In: B. Huang (ed.). Plant-environment interactions. CRC Press, Boca Raton, FL.

Roberts, S.K. and B.N. Snowman. 2000. The effects of ABA on channel mediated $\mathrm{K}^{+}$transport across higher plant roots. J. Expt. Bot. 51:15851594.

Roth, B.L., M. Poot, S.T. Yue, and P.J. Millard. 1997. Bacterial viability and antibiotic susceptibility testing with SYTOX green nucleic acid stain. Appl. Environ. Microbiol. 63:2421-2431.
Ruf, M. and I. Brunner. 2003. Vitality of tree fine roots: Reevaluation of the tetrazolium test. Tree Physiol. 23:257-263.

Shakirova, F.M., A.R. Sakhabutdinova, M.V. Bezrukova, R.A. Fatkhutdinova, and D.R. Fatkhutdinova. 2003. Changes in the hormonal status of wheat seedlings induced by salicylic acid and salinity. Plant Sci. 164:317-322.

Stevens, R.M., G. Harvey, and G. Davies. 1996. Separating the effects of foliar and root salt uptake on growth and mineral composition of four grapevine cultivars on their own roots and on 'Ramsey' rootstock. J. Amer. Soc. Hort. Sci. 121:569-575.

Truernit, E. and J. Haseloff. 2008. A simple way to identify non-viable cells within living plant tissue using confocal microscopy. Plant Methods 4:15.

Xu, C., T. Sibicky, and B. Huang. 2010. Protein profile analysis of salt-responsive proteins in leaves and roots in two cultivars of creeping bentgrass differing in salinity tolerance. Plant Cell Rpt. 29:595-615.

Yang, Z., J. Yu, E. Merewitz, and B. Huang. 2012. Differential effects of abscisic acid and glycine betaine on physiological responses to drought and salinity stress for two perennial grass species. J. Amer. Soc. Hort. Sci. 137:96-106.

Yurekli, F., Z. Banu Porgali, and I. Turkan. 2004. Variations in abscisic acid, indole-3-acetic acid, gibberellic acid and zeatin concentrations in two bean species subjected to salt stress. Acta Biol. Cracov. Ser. Bot. 46:201-212.

Yurekli, F., I. Turkan, Z. Banu Porgali, and S.F. Topcuoglu. 2001. Indoleacetic acid, gibberellic acid, zeatin, and abscisic acid levels in $\mathrm{NaCl}$-treated tomato species differing in salt tolerance. Isr. J. Plant Sci. 49:269-277.

Zorb, C., C.M. Geilfus, K.H. Muhling, and J. Ludwig-Muller. 2013. The influence of salt stress on ABA and auxin concentrations in two maize cultivars differing in salt resistance. J. Plant Physiol. 170:220 224. 